\title{
PENGARUH AUDIT COMMITTEE, OWNERSHIP STRUCTURE, DAN CHIEF \\ EXECUTIVE OFFICER TERHADAP FINANCIAL DISTRESS PADA PERUSAHAAN \\ SEKTOR PERDAGANGAN, JASA, DAN INVESTASI YANG TERDAFTAR DI BURSA EFEK INDONESIA PADA TAHUN 2015-2018
}

\author{
Refiana Dwi Maghfiroh \\ Universitas Negeri Surabaya \\ refianamaghfiroh16080574102@mhs.unesa.ac.id \\ Yuyun Isbanah \\ Universitas Negeri Surabaya \\ yuyunisbanah@unesa.ac.id
}

Abstract

Financial distress is a condition that occurs before a company goes bankrupt, so before that happens, the company needs to take actions such as good corporate governance practices. The purpose of this research is to determine the effect of the audit committee, ownership structure, and CEO on financial distress in trading, service, and investment companies listed on the Indonesia Stock Exchange for the period 2015-2018. The analysis technique used is logistic regression analysis. This type of research is quantitative by using a sample of 25 companies determined through a purposive sampling technique. The results showed that the frequency of audit committee meetings had a significant and positive impact on financial distress, and institutional ownership had a significant and negative impact on financial distress. While the other variables include: audit committee size, audit committee competence, audit committee independence, managerial ownership, family ownership, government ownership, foreign ownership, block holder ownership, and CEO's gender do not have a significant impact on financial distress. Implications of the results in this study are considering the frequency of audit committee meetings and the percentage of institutional ownership in predicting financial distress that can be used by companies and potential investors.

Keywords: Altman Z-score; audit committee; CEO gender; financial distress; ownership structure.

\section{PENDAHULUAN}

Kesulitan keuangan adalah suatu masalah yang dihadapi oleh perusahaan ketika pertumbuhan ekonomi Indonesia mengalami ketidakstabilan pada tahun 2015-2018. Dampak berupa penurunan pendapatan dan laba akan sangat memengaruhi kondisi keuangan perusahaan, serta dapat mengancam perusahaan mengalami kegagalan atau kebangkrutan. Menurunnya kondisi kemampuan keuangan merupakan keadaan tahap akhir perusahaan sebelum mengalami kerugian besar yang didefinisikan sebagai fase kesulitan keuangan (Platt \& Platt, 2002). Salah satu cara mengindikasi financial distress dalam perusahaan dapat diketahui melalui earning per share (EPS) perusahaan dengan nilai negatif selama beberapa periode, karena hal ini menggambarkan adanya penurunan kinerja yang dialami oleh perusahaan dan perusahaan terindikasi mengalami financial distress (Sunarwijaya, 2017).

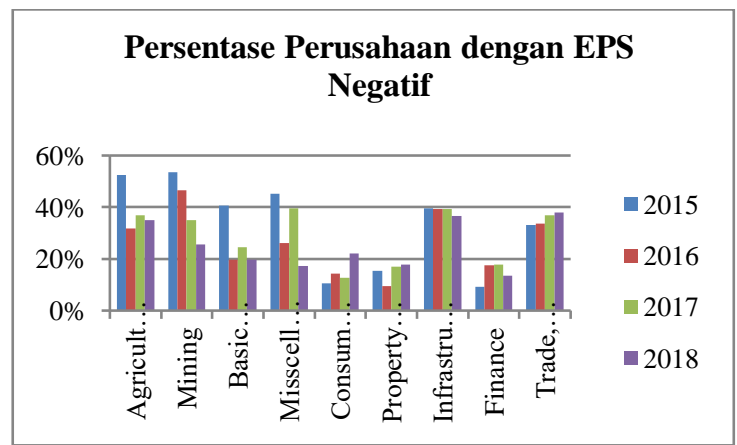

Sumber: IDX 2015-2018

Gambar 1. PERSENTASE PERUSAHAAN DENGAN EPS NEGATIF 
Refiana Dwi Maghfiroh \& Yuyun Isbanah. Pengaruh Audit Committee, Ownership Structure, dan Chief Executive Officer terhadap Financial Distress pada Perusahaan Sektor Perdagangan, Jasa, dan Investasi yang Terdaftar di Bursa Efek Indonesia pada Tahun 2015-2018

Gambar 1 menjelaskan bahwa pada sektor perdagangan, jasa, dan investasi selama periode 20152018, jumlah perusahaan dengan EPS negatif mengalami peningkatan dari tahun ke tahun, sehingga sektor tersebut terindikasi mengalami penurunan kinerja yang berdampak pada timbulnya financial distress.

Perusahaan dituntut untuk melakukan tindakan preventif salah satunya dengan aktualisasi mekanisme corporate governance berupa adanya karakteristik komite audit, struktur kepemilikan, serta gender chief executive officer (CEO) yang dapat memberikan peningkatan kemampuan kerja perusahaan sehingga dapat terlepas dari keadaan financial distress (Salloum et al., 2014).

Komite audit memiliki beberapa komponen yang dapat menunjang peran yang dijalankan diantaranya adalah ukuran, frekuensi pertemuan, kompetensi dan independensi komite audit (Revitasari et al., 2017). Optimalisasi kemahiran komite audit untuk kepentingan para stakeholders dapat terwujud melalui ketepatan jumlah komite audit sehingga masalah keagenan yang mengakibatkan financial distress dapat dihindarkan (Dalton et al., 1999). Tingkat pertemuan dinilai mampu menambah efektivitas peran komite audit, pertemuan yang semakin sering diadakan maka akan mempengaruhi tingkat pengawasan pada kinerja perusahaan secara berkala (McMullen \& Raghunandan, 1996). Independensi komite audit juga dapat memengaruhi kualitas kerja komite audit melalui laporan yang diberikan secara adil dan objektif sehingga dapat membangkitkan kepercayaan investor dan ketertarikan investor baru sehingga perusahaan terhindar dari permasalahan keuangan (Choy, et al,. 2011). Kemampuan anggota komite audit dalam bidang financial and accounting dapat berpengaruh pada kualitas monitoring dan evaluasi kinerja sehingga risiko financial distress dapat terhindarkan (Rahmat et al., 2009).

Beberapa studi menyatakan bahwa ukuran komite audit (Gunawijaya, 2015), independensi (Setiyani, 2014), frekuensi pertemuan dan kompetensi (Nuresa \& Hadiprajitno, 2015) secara negatif berpengaruh pada financial distress. Temuan lain menjelaskan hubungan positif ukuran komite audit (Siagian, 2010), frekuensi pertemuan (Gunawijaya, 2015), independensi dan kompetensi (Revitasari et al., 2017) dengan financial distress. Studi oleh Rahmawati \& Herlambang, (2018) yang mengungkapkan bahwa karakteristik komite audit dan financial distress tidak berpengaruh.

Struktur kepemilikan pada sebuah perusahaan dapat digunakan dalam upaya mencegah dan memprediksi financial distress (Manzaneque et al., 2016). Sejumlah studi terdahulu membagi struktur kepemilikan dalam suatu perusahaan yang mencakup kepemilikan institusional, manajerial, keluarga, asing, pemerintah serta blockholder. Kepemilikan institusi dapat meningkatkan pengawasan atas keputusan manajemen (Fathonah, 2017). Kepemilikan saham manajerial adalah salah satu aspek corporate governance sebagai upaya pemantauan yang mampu menghasilkan kualitas laporan yang baik (Sunarwijaya, 2017). Kepemilikan keluarga yang mendominasi dapat menekan kemungkinan konflik keagenan sehingga dapat mengakibatkan financial distress (Siagian, 2010). Pemilik saham pemerintah bertujuan untuk mendapatkan maksimalisasi keuntungan sehingga pengawasan dalam kinerja perusahaan akan diperketat (Udin et al., 2016). Kepemilikan saham oleh pihak asing pada sebuah perusahaan dapat membantu menaikkan performa keuangan perusahaan atas fungsinya sebagai pengawas dan memonitoring kinerja suatu perusahaan, selain itu pemegang saham asing juga mengedepankan profit (Udin et al., 2016). Pemilik saham blockholder akan cenderung melindungi kekayaan mereka yang telah diinvestasikan kepada perusahaan dan diharapkan mampu menunjang kualitas perusahaan sehingga berpengaruh pada keadaan financial distress (Donker et al., 2009).

Pengaruh kepemilikan institusional dan pemerintah (Hu \& Zheng, 2015), manajerial, asing, dan keluarga (Md-Rus et al., 2013); serta blockholder (Donker et al., 2009) secara signifikan negatif terhadap peningkatan financial distress. Studi lain memberikan temuan berbeda yang memaparkan bahwa kepemilikan institusi dan manajerial (Sunarwijaya, 2017), kepemilikan keluarga (Donker et al., 2009), kepemilikan pemerintah (Udin et al., 2016), kepemilikan asing (Abdullah et al., 2016), dan kepemilikan blockholder (Agustina et al., 2015) tidak mempengaruhi financial distress. Sedangkan beberapa studi menguraikan hasil signifikan positif kepemilikan institusional dan asing (Nurwaspodo, 
2016), kepemilikan manajerial (Fathonah, 2017), kepemilikan blockholder (Abdullah et al., 2016), kepemilikan keluarga (Siagian, 2010), dan kepemilikan pemerintah terhadap financial distress (Shahwan, 2015).

Financial distress juga dapat dipengaruhi akibat perbedaan gaya kepemimpinan female $C E O$ dan male $C E O$ yang berdampak pada perbedaan pengambilan keputusan dan kebijakan dalam perusahaan yang dapat berpengaruh pada kecilnya tingkat financial distress (Kristanti et al., 2016). Perbedaan hasil studi oleh Salloum \& Azoury (2012) menunjukkan bahwa tidak ditemukan pengaruh gender CEO dengan financial distres dan Sholikhah (2018) yang menyatakan pengaruh positif gender CEO pada financial distress.

Penelitian ini bertujuan untuk mengetahui dan mendeskripsikan pengaruh komite audit, struktur kepemilikan, dan gender CEO terhadap financial distress pada perusahaan sektor perdagangan, jasa, dan investasi pada kurun waktu periode tahun 2015-2018.

\section{KAJIAN PUSTAKA DAN PENGEMBANGAN HIPOTESIS}

\section{Agency Theory}

Agency theory merupakan suatu kontrak yang melibatkan agent dan principal akibat adanya pendelegasian kewenangan pengambilan keputusan oleh principal kepada agent (Jensen \& Meckling, 1976). Pemindahan tanggung jawab dapat menyebabkan suatu masalah agency yang disebabkan karena perbedaan kepentingan antara pemilik dengan pihak manajemen (Audit Quality Forum, 2005). Perbedaan kepentingan pemilik saham dengan bagian manajer perusahaan dapat menciptakan suatu biaya yang dinamakan agency cost, biaya ini dikeluarkan dengan tujuan agar perilaku manajer selaras dengan kepentingan yang diharapkan oleh para pemilik dari saham perusahaan (Jensen \& Meckling, 1976). Adanya teori agensi berfungsi sebagai suatu cara untuk menerapkan berbagai mekanisme terkait dengan tata kelola untuk pengendalian agen dalam perusahaan yang dimiliki bersama (Panda \& Leepsa, 2017)

\section{Financial Distress}

Indikator perusahaan financial distress pada studi ini ialah perusahaan dengan Earning Per Share (EPS) negatif. Perusahaan akan menunjukkan kinerja yang buruk dan terindikasi financial distress apabila nilai EPS bertanda negatif selama beberapa periode (Sunarwijaya, 2017). Financial distress merupakan variabel dependen yang dinyatakan dalam dummy variable di mana 0 (nol) didefinisikan perusahaan yang dikelompokkan tanpa indikasi financial distress dan 1 sebagai kelompok perusahaan dengan financial distress (Miglani et al., 2015). Pengategorian perusahaan ditetapkan melalui metode perhitungan Altman, di mana perusahaan dengan Z-Score $<1,1$ dikategorikan dalam perusahaan financial distress, dan sebaliknya (Altman \& Hotchkiss, 2006:267).

\section{Corporate Governance}

Corporate governance dimaknai sebagai kebijakan yang mencakup tatanan hak dan kewajiban antara pihak investor, manajemen, kreditur, karyawan, pemerintah, serta pemangku kepentingan pihak internal ataupun eksternal perusahaan (FCGI, 2001). Corporate governance mampu meminimalkan masalah keagenan sebab seluruh hak pemilik saham dan jaminan kesetaraan kepentingan dari principal serta agent yang telah tersusun pada mekanisme yang ada didalamnya (Hanifah \& Purwanto, 2013). Implementasi good corporate governance penting dalam menopang kualitas kerja keuangan perusahaan sehingga dapat mengantisipasi ancaman financial distress (Sundari \& Amiruddin, 2015).

\section{Komite Audit}

Konflik agensi yang menjadi penyebab finansial distress dapat diminimalkan dengan mengaplikasikan corporate governance yang salah satunya diimplementasikan oleh kehadiran komite audit (Hanifah \& Purwanto, 2013). Pembentukan komite audit di sebuah perusahaan bertujuan sebagai pengawas yang bersifat independen dalam proses laporan keuangan, kontrol perusahaan, serta 
Refiana Dwi Maghfiroh \& Yuyun Isbanah. Pengaruh Audit Committee, Ownership Structure, dan Chief Executive Officer terhadap Financial Distress pada Perusahaan Sektor Perdagangan, Jasa, dan Investasi yang Terdaftar di Bursa Efek Indonesia pada Tahun 2015-2018

pelaporan corporate governance (Rahmawati \& Herlambang, 2018). Karakteristik yang dimiliki komite audit digunakan untuk memastikan praktik terbaik corporate governance dan meminimalkan ancaman financial distress yang dirasakan perusahaan (Nuresa \& Hadiprajitno, 2015; Revitasari et al., 2017)

\section{Ukuran Komite Audit}

Keseluruhan jumlah komite audit yang aktif pada suatu perusahaan dalam melaksanakan tanggung jawabnya diartikan sebagai ukuran komite audit (Masak \& Noviyanti, 2019). Agar pelaksanaan tanggung jawab yang meliputi pengendalian dan monitoring terhadap aktivitas perusahaan tercapai secara optimal maka kebutuhan jumlah anggota komite audit selayaknya dapat tercukupi (Kristanti \& Syafruddin, 2012). Perhitungan ukuran komite audit dapat dilihat di rumus (1) (Rahmat et al., 2009).

$S Z_{A C}=\Sigma$ Jumlah Anggota Komite Audit

\section{Frekuensi Pertemuan Komite Audit}

Frekuensi pertemuan dideskripsikan melalui banyaknya rapat yang dilakukan oleh komite audit dalam satu tahun (Revitasari et al., 2017). Pertemuan komite audit berguna untuk media penghubung secara formal antara satu anggota dengan yang lain guna memenuhi tugas dan tanggungjawab terkait dengan pengendalian dan pengawasan internal (Sundari \& Amiruddin, 2015). Perhitungan frekuensi pertemuan komite audit dapat dilihat di rumus (2) (Salloum et al., 2014).

$F Q_{A C}=\Sigma$ Rapat Komite Audit

\section{Independesi Komite Audit}

Pihak luar yang tidak memiliki hubungan serta tidak sebagai pemilik saham di perusahaan dan menjabat sebagi komite audit merupakan definisi terkait independensi komite audit (Revitasari et al., 2017). Tujuan utama independensi ialah untuk menjaga kredibilitas dan penilaian yang objektif pada laporan serta anjuran yang berkualitas, sebab pribadi yang mandiri memiliki kecenderungan bertindak secara adil serta objektif dalam menangani sebuah masalah (FCGI, 2001). Perhitungan independensi komite audit dapat dilihat di rumus (3) (Kristanti \& Syafruddin, 2012)

$$
I N D_{A C}=\frac{\Sigma \text { Jumlah Komisaris Independen }}{\Sigma \text { Total Anggota }} X 100 \%
$$

\section{Kompetensi Komite Audit}

Kompetensi merupakan komite audit yang memiliki spesialisasi dan kapabilitas dalam aspek keuangan yang ditunjukkan melalui kuantitas anggota yang memiliki pengetahuan dibidang financial and accounting karena dalam menjalankan pekerjaannya, komite audit dituntut memahami dan mengerti serta dapat menganalisa laporan keuangan (Sundari \& Amiruddin, 2015). Perhitungan kompetensi komite audit dapat dilihat di rumus (4) (Rahmat et al., 2009)

$$
C M P T_{A C}=\Sigma \text { Jumlah Komite Audit yang Berkompeten }
$$

\section{Struktur Kepemilikan}

Struktur kepemilikan adalah besarnya pihak yang memegang saham dalam suatu perusahaan yang memiliki fungsi sebagai pemantau kinerja dalam perusahaan (Miglani et al., 2015). Struktur kepemilikan mencakup komponen kepemilikan yang merujuk pada adanya identitas pemegang saham, konsentrasi kepemilikan yang mengacu pada total lembar saham perusahaan yang hak miliknya dipegang oleh pemilik saham, serta pemisahan kepemilikan yang mengacu pada perbedaan hak aliran kas serta hak kontrol pemegang saham besar (Hu \& Zheng, 2015). Adanya kepemilikan yang terkonsentrasi dalam suatu perusahaan maka pemegang saham memiliki kekuatan untuk melindungi kepentingan mereka dan secara aktif membantu memonitor kinerja perusahaan serta dapat menggunakan kekuatan voting mereka untuk membuat perubahan yang diperlukan dalam perusahaan tersebut (Li et al., 2008). 


\section{Kepemilikan Institusional}

Kepemilikan institusional dimaknai dengan besaran persentase saham pihak intitusi dari keseluruhan jumlah saham beredar (Nurwaspodo, 2016). Manfaat kepemilikan institusional adalah sebagai pengendali dari pihak manajemen perusahaan menggunakan sistem monitoring secara efektif (Nuresa \& Hadiprajitno, 2015). Perhitungan kepemilikan institusional dapat dilihat di rumus (5) (Sunarwijaya, 2017).

$I N S_{O W N}=\frac{\Sigma \text { Saham Institusional }}{\Sigma \text { Total Saham }} \times 100 \%$

\section{Kepemilikan Manajerial}

Dengan kepemilikan manajerial, maka kepentingan pemegang saham akan lebih dipantau secara efektif karena pihak manajerial memiliki beberapa risiko sebagai pemegang saham (Li et al., 2008). Perhitungan kepemilikan manajerial didapat dari persentase total saham beredar suatu perusahaan yang terbagi atas saham yang dipegang oleh manajemen (Sunarwijaya, 2017) yang dapat dilihat di rumus (6).

$M A N_{O W N}=\frac{\Sigma \text { Saham Manajerial }}{\Sigma \text { Total Saham }} \times 100 \%$

\section{Kepemilikan Keluarga}

Kepemilikan keluarga merupakan besarnya persentase lembar saham yang menjadi hak milik pihak keluarga (Donker et al., 2009). Keluarga mencerminkan suatu golongan khusus dari pemegang saham yang secara potensi memiliki struktur insentif dan kekuasaan di perusahaan dalam memberikan keputusan (Sugiarto, 2009:24). Perhitungan kepemilikan keluarga dapat dilihat di rumus (7) (Md-Rus et al., 2013).

$F A M_{O W N}=\frac{\Sigma \text { Saham Keluarga }}{\Sigma \text { Total Saham }} \times 100 \%$

\section{Kepemilikan Pemerintah}

Kepemilikan pemerintah diartikan menjadi lembar saham yang kepemilikannya dipegang oleh departemen /lembaga negara yang disahkan oleh pemerintah. Perusahaan dengan saham yang dimiliki pemerintah biasanya mendapatkan dukungan ketika menghadapi financial distress (Hu \& Zheng, 2015). Perhitungan kepemilikan pemerintah dapat dilihat di rumus (8) (Li et al., 2008).

GOV $_{\text {OWN }}=\frac{\Sigma \text { Saham Pemerintah }}{\Sigma \text { Total Saham }} \times 100 \%$

\section{Kepemilikan Asing}

Kepemilikan asing ialah besarnya persentase saham suatu perusahaan yang haknya dipegang oleh individu, pemerintahan, lembaga hukum, dan lainnya yang berstatus luar negeri atau asing (Rinaldi, 2014). Adanya kepemilikan asing dalam suatu perusahaan biasanya terdapat pemantauan dari manajer yang kuat (Md-Rus et al., 2013). Perhitungan kepemilikan asing dapat dilihat di rumus (9) (Udin et al., 2016).

$F R G_{O W N}=\frac{\sum \text { Saham Asing }}{\sum \text { Total Saham }} \times 100 \%$

\section{Kepemilikan Blockholder}

Kepemilikan blockholder adalah saham milik individu non institusi dan non direktur yang besarnya melebihi 5\% dan tidak berafiliasi dengan pihak manajemen (Elloumi \& Gueyié, 2001). Adanya blockholder dapat memberikan rekomendasi kepada direksi ketika kinerja yang dihasilkan di bawah standar atau kapasitasnya, sehingga membuat manajer cepat dalam mengambil tindakan tertentu (Miglani et al., 2015). Perhitungan kepemilikan blockholder dapat dilihat di rumus (10) (Donker et al., 2009). 
Refiana Dwi Maghfiroh \& Yuyun Isbanah. Pengaruh Audit Committee, Ownership Structure, dan Chief Executive Officer terhadap Financial Distress pada Perusahaan Sektor Perdagangan, Jasa, dan Investasi yang Terdaftar di Bursa Efek Indonesia pada Tahun 2015-2018

$B L C K_{O W N}=\frac{\Sigma \text { Saham blockholder }}{\Sigma \text { Total Saham }} \times 100 \%$

\section{Gender Chief Executive Officer (CEO)}

CEO merupakan jabatan tertinggi yang bertanggung jawab atas kepemimpinan dan perannya penting dalam penciptaan kondisi untuk kinerja keseluruhan anggota perusahaan (Salloum \& Azoury, 2012). Gender pada suatu organisasi dapat memberikan persepsi baru dalam prosedur pengambilan keputusan, mengontrol keefektifan tata kelola perusahaan, menciptakan ide baru dan kreativitas sehingga menghasilkan suatu keunggulan kompetitif dan menentukan keberhasilan perusahaan (Sholikhah, 2018). Gender CEO dapat diketahui menggunakan variabel dummy yaitu 0 (nol) jika CEO berjenis kelamin laki-laki, dan 1 jika CEO berjenis kelamin perempuan (Abdullah et al., 2016).

\section{Hubungan antar Variabel}

Ukuran komite audit dapat berkontribusi pada keberhasilan peran komite audit dalam mengatasi konflik keagenan. Efektivitas komite audit akan tercapai bila mempunyai tenaga kerja yang mencukupi dalam mengatasi persoalan yang dialami perusahaan, sehingga komite audit dapat memperbaiki kebijakan dalam mencapai laba perusahaan yang berdampak pada terhindarnya kondisi financial distress karena kinerja keuangan yang baik (Nuresa \& Hadiprajitno, 2015). Komite audit dengan ukuran yang besar mampu mengoptimalkan kualitas pengawasan internal dan mengurangi ancaman financial distress (Masak \& Noviyanti, 2019). Berbeda dengan penelitian lain menjelaskan bahwa tingkat partisipasi anggota lebih tinggi apabila komite audit memiliki ukuran yang kecil, sedangkan komite audit dengan ukuran skala besar dapat memantau proses pelaporan secara efisien (Salloum et al., 2014).

H1: Ukuran komite audit berpengaruh terhadap financial distress pada perusahaan sektor perdagangan, jasa, dan investasi pada tahun 2015-2018.

Besarnya frekuensi pertemuan oleh komite audit akan berdampak pada komunikasi antar anggota yang lebih terstruktur serta dapat mengantisipasi ketidaksesuaian praktik dengan kebijakan perusahaan karena pengendalian internal yang dilakukan terus menerus sehingga komite audit dapat mengetahui lebih cepat permasalahan dan penyimpangan yang terjadi sehingga perusahaan pun akan bebas dari keadaan financial distress (Nuresa \& Hadiprajitno, 2015). Tingginya tingkat frekuensi pertemuan mampu meningkatkan kinerja perusahaan sebab komite audit dapat menanggung kewajiban mereka dan menjamin integritas laporan keuangan perusahaan untuk melaksanakan pengawasan yang lebih baik serta memantau efektivitas operasional (Salloum et al., 2014)

$\mathrm{H} 2$ : Frekuensi pertemuan komite audit berpengaruh terhadap financial distress pada perusahaan sektor perdagangan, jasa, dan investasi pada tahun 2015-2018

Kehadiran mayoritas pihak eksternal dalam komite audit dapat mengoptimalkan tingkat independensi dan mutu komite audit melalui opini secara objektif dan independen serta memberikan masukan yang berkaitan dengan kebijakan manajemen, sehingga tingginya persentase komite audit yang tidak terafiliasi, maka berdampak pada rendahnya probabilitas kesulitan keuangan (Salloum et al., 2014). Penyampaian pendapat yang bersifat objektif kepada manajemen puncak dari komite audit yang independen perlu dipertimbangkan karena potensi mereka untuk bertindak lebih independen (Rahmat et al., 2009).

H3: Independensi komite audit berpengaruh terhadap financial distress pada perusahaan sektor perdagangan, jasa, dan investasi pada tahun 2015-2018.

Komite audit dengan latarbelakang kecakapan dalam bidang financial and accounting dapat mengawasi dan mengontrol operasional dan keuangan perusahaan secara efektif serta diharapkan dapat menggunakan standar akuntabilitas, menambah tingginya tingkat pencapaian target, serta meningkatkan keunggulan kinerja perusahaan dan dapat mengurangi peluang munculnya financial 
distress (Rahmat et al., 2009). Pengalaman dan keahlian komite audit dalam hal financial and accounting dapat meminimalkan risiko kesalahan dalam penyajian laporan keuangan, karena pengendalian dan pemantauan kinerja yang berkualitas (Fuad, 2017). Timbulnya konflik keagenan pada perusahaan yang menyebabkan financial distress dapat dicegah, sebab adanya pengetahuan keuangan dapat meniadakan upaya agent untuk memalsukan informasi keuangan dan akuntansi perusahaan (Nuresa \& Hadiprajitno, 2015).

H4: Kompetensi komite audit berpengaruh terhadap financial distress pada perusahaan sektor perdagangan, jasa, dan investasi pada tahun 2015-2018.

Pemegang saham institusional bertindak sebagai agen pemantau dalam suatu perusahaan sehingga semakin banyak saham milik investor institusional maka probabilitas financial distress yang mungkin dihadapi oleh perusahaan akan berkurang (Md-Rus et al., 2013). Investor institusional memantau secara profesional perkembangan investasi sahamnya dan juga berperan untuk mencegah tindakan inefisiensi dan kecurangan yang dilakukan oleh manajemen sebab tingkat pengendalian terhadap manajemen sangat tinggi (Siagian, 2010). Perusahaan yang mayoritas sahamnya dipegang oleh pemegang saham institusional mendapatkan tekanan yang lebih kompetitif karena tujuan utama pemegang saham institusional adalah untuk mendapatkan laba yang lebih tinggi dan lebih memperhatikan peningkatan nilai perusahaan pada jangka panjang sehingga pemegang saham institusional lebih aktif dalam manajemen pemantauan, yang berdampak pada kemungkinan kondisi financial distress yang lebih kecil (Hu \& Zheng, 2015).

H5: Kepemilikan institusional berpengaruh terhadap financial distress pada perusahaan sektor perdagangan, jasa, dan investasi pada tahun 2015-2018.

Dalam asumsi keagenan, kepemilikan manajerial merupakan faktor yang dapat meminimalkan konflik kesenjangan kepentingan yang muncul, sehingga hal tersebut dapat mengurangi probabilitas financial distress yang diderita perusahaan (Manzaneque et al.,2016). Kepemilikan manajerial yang lebih besar berkaitan dengan masalah agensi yang lebih rendah setelah adanya pengendalian untuk mekanisme tata kelola dan pencegahan masalah keagenan (Miglani et al., 2015), dengan kata lain besarnya jumlah saham direksi maka semakin besar pula motivasi mereka dalam memaksimalkan kekayaan bisnis melalui strategi jangka panjang dikarenakan direksi mendapatkan manfaat yang besar dari kegiatan investasinya (Manzaneque et al., 2016) sehingga kepemilikan manajerial memiliki pengaruh negatif pada risiko kegagalan bisnis atau financial distress. Pendapatan serta kerugian manajer sebagai pemilik saham jauh lebih besar daripada manajer yang tidak memiliki saham diperusahaan, oleh sebab itu kepemilikan saham dapat memotivasi manajer untuk bekerja dengan efisien (Donker $e t$ al., 2009).

H6: Kepemilikan manajerial berpengaruh terhadap financial distress pada perusahaan sektor perdagangan, jasa, dan investasi pada tahun 2015-2018.

Adanya kepemilikan keluarga di perusahaan umumnya memiliki sistem pemantauan yang makin baik yang mengarah pada minimalnya masalah keagenan, namun kepemilikan keluarga juga dapat menyebabkan ketidakjelasan peran dan tanggung jawab antara pemegang saham keluarga dan manajer keluarga (Md-Rus et al., 2013). Kepemilikan keluarga juga secara efisien dapat memaksimalkan nilai dari perusahaan dikarenakan adanya insentif yang besar dari pihak keluarga untuk memantau karena proporsi kekayaan mereka yang lebih tinggi diinvestasikan dalam perusahaan (Musallam et al., 2019). Pihak keluarga dengan persentase kepemilikan yang signifikan dalam sebuah perusahaan, maka keluarga tersebut memiliki insentif yang besar dalam memastikan bahwa perusahaan memiliki capaian kinerja yang baik (Md-Rus et al., 2013). Kendali dan dominasi oleh pendiri memberikan manfaat yang lebih baik dikarenakan mampu mengurangi serta meredakan adanya konflik kesenjangan kepentingan dari pemilik saham dan manajer (Siagian, 2010).

H7: Kepemilikan keluarga berpengaruh terhadap financial distress pada perusahaan sektor perdagangan, jasa, dan investasi pada tahun 2015-2018. 
Refiana Dwi Maghfiroh \& Yuyun Isbanah. Pengaruh Audit Committee, Ownership Structure, dan Chief Executive Officer terhadap Financial Distress pada Perusahaan Sektor Perdagangan, Jasa, dan Investasi yang Terdaftar di Bursa Efek Indonesia pada Tahun 2015-2018

Perusahaan dengan kepemilikan pemerintah biasanya mendapatkan dukungan ketika menghadapi financial distress dan cenderung terbebani dengan beberapa tanggungjawab publik berupa mempromosikan karir karyawan dan memerhatikan stabilitas ekonomi negara (Hu \& Zheng, 2015). Dampak financial distress yang dapat menganggu kelangsungan hidup dan fungsi perusahaan publik dengan pemegang saham negara, mendorong pemerintah sebagai pemegang saham memberikan perhatian lebih atau dengan kata lain pemerintah tidak mungkin mengabaikan kinerja perusahaan yang dapat mengganggu peran perusahaan dalam membangun perekonomian negara (Li et al., 2008). Selain faktor tersebut, para manajer perusahaan yang dipilih secara birokratis, akan memberikan upaya yang optimal untuk berjuang melawan kesulitan agar terlindung dari sisi prospek politiknya(Udin et al., 2016).

H8: Kepemilikan pemerintah berpengaruh terhadap financial distress pada perusahaan sektor perdagangan, jasa, dan investasi pada tahun 2015-2018.

Kepemilikan saham asing menjadi salah satu penentu tata kelola perusahaan yang bisa meminimalkan financial distress karena investor asing lebih profesional dan memiliki kemampuan yang baik dalam pemantauan dan pengendalian, serta memberikan insentif kepada para manajer untuk meningkatkan kinerja keuangan perusahaan (Abdullah et al., 2016). Alasan lain adalah karena adanya transfer teknologi dan praktik tata kelola yang memiliki kualitas tinggi oleh perusahaan asing yang dapat mempercepat laju kinerja keuangan perusahaan dan mengurangi kemungkinan financial distress (Udin et al., 2016). Perusahaan dengan saham milik asing secara umum merupakan perusahaan yang unggul dan memiliki manajer dengan sistem pemantauan yang baik pula sehingga kemungkinan financial distress yang dialami oleh perusahaan juga lebih rendah serta dapat menjadi bentuk praktik good corporate governance untuk menekan masalah agen yang ditimbulkan akibat dari sikap pemegang saham pengendali yang mencari keuntungan secara pribadi (Md-Rus et al., 2013).

H9: Kepemilikan asing berpengaruh terhadap financial distress pada perusahaan sektor perdagangan, jasa, dan investasi pada tahun 2015-2018.

Pemilik saham blockholder memberikan pemantauan yang efektif karena pemegang saham blockholder memiliki kesempatan untuk meningkatkan strategi perusahaan dengan memberikan insentif ataupun pengaruh kepada manajer dalam perusahaan untuk mengambil tindakan yang tepat yang dapat memberikan keuntungan bagi perusahaan dan mengurangi kecurangan yang dilakukan perusahaan (Donker et al., 2009). Kehadiran blockholder dalam suatu perusahaan memiliki insentif kepada manajer untuk mengambil tindakan tertentu serta sebagai mekanisme kontrol internal, dan dapat mencegah manajer berperilaku oportunistik serta mencegah kegagalan bisnis (Elloumi \& Gueyié, 2001; Miglani et al., 2015).

H10: Kepemilikan blockholder berpengaruh terhadap financial distress pada perusahaan sektor perdagangan, jasa, dan investasi pada tahun 2015-2018.

CEO dengan gender wanita dinilai mudah beradaptasi, serta mudah juga untuk mendesak lawan dan meningkatkan persaingan didalam perusahaan tersebut sehingga lebih meminimalkan dampak dari financial distress (Salloum \& Azoury, 2012). Burke (1994) berpendapat bahwa wanita yang memiliki jabatan seorang direktur akan memainkan peran dalam membesarkan dan melakukan diskusi terhadap masalah yang dialami oleh perusahaan, baik didalam ataupun diluar dikarenakan bahwa CEO wanita akan membawa perubahan, membawa manfaat tambahan dari direktur wanita dalam menggali potensi keuntungan perusahaan dan menekan tingkat kesulitan keuangan. Investor dan mitra kerja juga mempercayai jika direktur wanita akan lebih berkontribusi terhadap peningkatan nilai-nilai perusahaan.

H11: Gender CEO berpengaruh terhadap financial distress pada perusahaan sektor perdagangan, jasa, dan investasi pada tahun 2015-2018. 


\section{METODE PENELITIAN}

Studi ini merupakan kuantitatif kausalitas yang mempergunakan data sekunder yang bersumber pada financial dan annual report perusahaan yang diperoleh dari website resmi perusahaan dan IDX. Populasi pada studi merupakan perusahaan yang terdaftar pada sektor perdagangan, jasa, dan investasi di Bursa Efek Indonesia tahun 2015-2018, dengan sampel sebesar 25 perusahaan yang ditentukan menggunakan teknik purposive sampling, meliputi kriteria (1) perusahaan yang mempublikasi laporan tahunan dan keuangan pada periode 2015-2018 (2) EPS bernilai negatif minimal dua periode berturutturut (3) mencantumkan informasi secara lengkap mengenai komite audit, struktur kepemilikan, dan CEO. Analisis statistik yang dipakai adalah logistic regression dengan menggunakan software SPSS. Persamaan yang dirumuskan dari studi ini dapat dilihat di rumus (11).

$$
\begin{aligned}
\operatorname{Ln} \frac{p}{p-1}= & \alpha+\beta 1 . S Z_{A C}+\beta 2 . F Q_{A C}+\beta 3 . I N D_{A C}+\beta 4 . C M P T_{A C}+\beta 5 . I N S_{O W N}+\beta 6 . M A N_{O W N}+ \\
& \beta 7 . F A M_{O W N}+\beta 8 . G O V_{O W N}+\beta 9 . F R G_{O W N}+\beta 10 . B L C K_{O W N}+\beta 11 . G N D R_{C E O}+\mathrm{e} . .(11)
\end{aligned}
$$

\section{HASIL DAN PEMBAHASAN}

\section{Overall Model Fit}

Nilai -2Log Likelihood block 0 sebesar 138,589 dan nilai -2Log Likelihood block 1 sebesar 112,360. Hal tersebut menunjukkan adanya selisih nilai -2Log Likelihood sebesar 26,230 dengan df 11 (99-88), maka H0 diterima sehingga dapat memperlihatkan bahwa model regresi logistik pada studi secara keseluruhan fit dengan data.

\section{Hosmer and Lemeshow's of Fit Test}

Hasil uji yang dilakukan untuk mengetahui signifikansi dalam Hosmer Lemeshow's Goodness of Fit Test sebesar 0,114 > 0,05 memiliki arti bahwa model dapat diterima dan dapat mengimplikasi bahwa uji regresi logistik studi ini layak untuk dipergunakan selanjutnya karena nilai observasi dapat diprediksi oleh model.

\section{Nagelkerke R Square}

Diketahui bahwa hasil uji yang diperoleh sebesar 0,308 yang mengindikasi bahwa variabel bebas yang dipergunakan dalam studi ini bisa menjelaskan keberagaman pada variabel terikat dengan persentase sebesar 30,8\% sedangkan sebesar $69,2 \%$ dideskripsikan oleh variabel yang tidak termasuk dalam studi ini.

\section{Matrik Klasifikasi}

Studi ini mempergunakan sampel yang terdiri dari 25 perusahaan dan dikalikan dengan kurun waktu penelitian yakni selama empat periode sehingga menghasilkan sebanyak 100 data sampel perusahaan yang termasuk kedalam financial distress dan non-financial distress. Berdasarkan hasil yang diperoleh dari matrik klasifikasi, memperlihatkan bahwa dalam kategori non-financial distress terdapat 49 data sampel yang dapat diprediksi, namun hanya sebanyak 39 yang dapat terobservasi secara tepat dengan perolehan persentase sebesar 79,6\% (39/49). Pada kategori financial distress hasil data yang dapat diprediksi sebanyak 51 , namun hanya sebanyak 35 data sampel yang dapat terobservasi secara tepat dengan persentase sebesar $68,6 \%(35 / 51)$.

\section{Uji Estimasi Parameter dan Interpretasi}

Model regresi logistik yang dihasilkan dari penelitian ini dapat dilihat pada persamaan (12).

$\operatorname{Ln} \frac{P}{P-1}=-4,338+0,526 F Q_{A C}-0,02 I N S_{O W N}+\mathrm{e}$

Hasil uji wald pada variabel frekuensi pertemuan komite audit memperoleh $P$ value sebesar $0,006<$ 0,05 yang menunjukkan pengaruh yang terdapat antara frekuensi pertemuan komite audit dengan financial distress, dengan arah pengaruh positif dikarenakan nilai $\beta(0,526)$ yang bermakna semakin 
Refiana Dwi Maghfiroh \& Yuyun Isbanah. Pengaruh Audit Committee, Ownership Structure, dan Chief Executive Officer terhadap Financial Distress pada Perusahaan Sektor Perdagangan, Jasa, dan Investasi yang Terdaftar di Bursa Efek Indonesia pada Tahun 2015-2018

tinggi tingkat pertemuan komite audit maka meningkatkan financial distress. Variabel kepemilikan institusi memiliki nilai $\mathrm{P}$ value uji wald sejumlah $0,041<0,05$ yang menunjukkan pengaruh yang terdapat dalam kepemilikan institusi terhadap financial distress bersifat signifikan dengan arah pengaruh negatif dikarenakan nilai $\beta(-0,26)$ mengindikasi semakin tinggi kepemilikan institusi maka akan menurunkan tingkat financial distress.

Tabel 1.

VARIABLES IN THE EQUATION

\begin{tabular}{llcc}
\hline & Variable & B & Sig. \\
\hline & SZ_AC &, 618 &, 383 \\
& FQ_AC &, 526 &, 006 \\
& INDP_AC &, 002 &, 832 \\
& CMPT_AC &, 507 &, 202 \\
& INS_OWN &,- 026 &, 041 \\
Step 1 1 & MAN_OWN &, 021 &, 629 \\
& FAM_OWN &, 015 &, 077 \\
& GOV_OWN & 17,146 &, 999 \\
& FRG_OWN &, 005 &, 591 \\
& BLCK_OWN &,- 057 &, 177 \\
& GNDR_CEO &,- 349 &, 645 \\
& Constant & $-4,338$ &, 080 \\
\hline Sumber: & Output SPSS (2020, data diolah) &
\end{tabular}

\section{Pengaruh Ukuran Komite Audit terhadap Financial Distress}

Temuan yang tertera pada tabel 1, mengindikasi bahwa H1 ditolak. Uji regresi logistik ini menafsirkan bahwa tidak terdapat pengaruh secara signifikan dari ukuran komite audit pada financial distress. Banyaknya anggota komite audit dinilai tidak bisa mendukung keberhasilan kerja komite audit. Faktor lain juga disebabkan karena didapati beberapa perusahaan dengan anggota komite audit berjumlah lebih atau kurang dari tiga orang, hal tersebut tidak sesuai dengan regulasi yang ditetapkan oleh Otoritas Jasa Keuangan No.55/POJK.04/2015 yang mengatur mengenai anggota minimum komite audit yang berjumlah tiga orang. Pernyataan tersebut sesuai dengan Dalton et al., (1999) yang menunjukkan apabila komite audit kurang efektif jika memiliki anggota yang terlalu sedikit maupun terlalu besar, komite audit dengan ukuran yang terlalu kecil dapat menyurutkan keberagaman keterampilan dan pengetahuan sedangkan jumlah yang terlalu besar dapat menghilangkan fokus dan kurangnya partisipasi anggota dalam menyelesaikan konflik. Interpretasi teori temuan dalam studi tidak didukung oleh adanya agency theory yang menguraikan bahwa ukuran komite audit dapat mengatasi masalah keagenan karena fungsi pengawasan internal serta kontrol komite audit dapat dijalankan dengan baik bila memiliki jumlah anggota yang memadai. Interpretasi praktis hasil penelitian ini adalah perusahaan dapat lebih berfokus pada keefektifan tugas dan kewajiban komite audit dalam menjalankan pengawasan agar dapat menunjang kinerja dan daya saing perusahaan.

\section{Pengaruh Frekuensi Pertemuan Komite Audit terhadap Financial Distress}

Uji regresi logistik pada tabel 1 dapat diartikan bahwa $\mathrm{H} 2$ diterima, yang menunjukkan bahwasanya ditemukan pengaruh dengan arah positif dari frekuensi pertemuan yang diadakan oleh komite audit pada tingkat financial distress, yang dimaknai apabila frekuensi pertemuan komite audit semakin tinggi maka besar kemungkinan financial distress mengalami peningkatan. Seringnya pertemuan yang diadakan oleh komite audit mengindikasi bahwa terdapat banyak masalah yang dialami perusahaan, sehingga pertemuan komite audit diadakan untuk mengkaji dan menyelesaikan masalah-masalah yang terjadi dalam perusahaan, seperti halnya yang terjadi pada PT. Modern International Tbk dan PT. Renuka Coalindo Tbk yang lebih banyak mengadakan pertemuan pada waktu satu periode ketika perusahaan sedang mengalami financial distress. Idealnya rapat diadakan sebanyak empat kali selama satu periode seperti yang dimuat pada ketetapan OJK No.55/POJK.04/2015. Interpretasi teori hasil studi tidak konsisten dengan pernyataan agency theory yang memaparkan jika pertemuan komite audit 
dapat meningkatkan kemampuan perusahaan dan menjauhkan perusahaan dari ancaman financial distress karena tingginya frekuensi pertemuan komite audit dapat mencegah munculnya masalah dan proses pengawasan internal lebih optimal. Interpretasi praktis temuan pada studi ini adalah perusahaan tetap perlu memperhatikan tingkat pertemuan komite audit dan mengetahui permasalahan yang sedang dibahas pada pertemuan komite audit, dikarenakan semakin tingginya frekuensi pertemuan komite audit dapat mengindikasi bahwasanya perusahaan tersebut memiliki beberapa masalah yang harus diselesaikan.

\section{Pengaruh Independensi Komite Audit terhadap Financial Distress}

Nilai signifikansi independensi pada komite audit di tabel 1 bermakna $\mathrm{H} 3$ tidak dapat diterima, yang menunjukkan tidak terdapat pengaruh independensi komite audit pada financial distress. Tidak didapati pengaruh secara signifikan independensi komite audit pada kondisi financial distress dikarenakan independensi anggota komite audit hanya bentuk formalitas kepatuhan perusahaan pada aturan OJK No.55/POJK.04/2015, namun tidak diimbangi dengan pengoptimalan fungsi pengawasan secara independen dari komite audit, sehingga tingkat independensi tidak dapat meningkatkan efektivitas komite audit serta tidak dapat memberikan efek terhadap kondisi financial distress. Mekanisme pemilihan anggota komite audit yang tidak transparan dan kurang kejelasan juga memberikan keraguan pada independensi anggota komite audit, seperti halnya bila anggota komite audit terdapat hubungan khusus dengan pihak manajemen, sehingga hal tersebut dapat mengurangi independensi yang berkualitas dari komite audit pada sebuah perusahaan. Interpretasi teori hasil studi tidak selaras dengan pernyataan agensi teori yang menyebutkan bahwasanya tingkat independensi komite audit akan mengoptimalkan fungsi pengendalian internal melalui opini yang faktual dan independen serta mampu memberikan saran terkait kebijakan yang diterapkan oleh manajemen sehingga dapat memberikan nilai tambah pada kinerja perusahaan dan meminimalkan risiko financial distress. Interpretasi praktis pada temuan ini adalah perusahaan tetap memperhatikan komposisi independensi komite audit yang sejalan dengan aturan, namun juga harus memperhatikan penilaian yang objektif dan independen terhadap perusahaan, dengan tujuan agar terhindar dari ancaman financial distress.

\section{Pengaruh Kompetensi Komite Audit terhadap Financial Distress}

Hasil yang diperoleh dari tabel 1, memperlihatkan bahwa H4 ditolak. Analisa dari regresi logistik menjelaskan apabila kompetensi komite audit terbukti tidak memiliki pengaruh pada financial distress. Pembentukan anggota dalam komite audit yang berkompeten pada bidang financial and accounting merupakan bentuk kepatuhan perusahaan dalam aturan yang ditetapkan OJK No.55/POJK.04/2015 yang mengharuskan komite audit terdiri dari minimal satu anggota yang berlatar belakang pendidikan serta kompetensi di bidang financial and accounting. Namun, tindakan tersebut tidak diimbangi dengan optimalisasi kualitas pengawasan dari komite audit. Kompetensi komite audit yang baik, tidak cukup bila hanya mengandalkan satu bidang kompetensi, namun juga harus berwawasan luas seperti pemahaman terhadap ilmu hukum, regulasi pasar modal, prosedur industri dan bisnis terkait guna mendukung peran fungsi komite audit perusahaan (Setiyani, 2014). Sampel perusahaan dalam penelitian ini mengindikasi tidak adanya perbedaan secara signifikan mengenai jumlah anggota komite audit yang memiliki kompetensi, sehingga kompetensi komite audit tidak ditemukan pengaruh secara signifikan dengan financial distress. Implikasi teoritis temuan studi tidak selaras dengan agency theory, di mana kompetensi komite audit dapat menambah pengawasan keuangan perusahaan secara efektif serta dapat meningkatkan standar akuntabilitas sehingga dapat menopang kinerja perusahaan dan mencegah terjadinya financial distress pada perusahaan. Interpretasi praktis dari hasil studi ini adalah perusahaan tetap memperhatikan komposisi anggota komite audit yang berkompeten sebagai bentuk kepatuhan terhadap aturan namun harus mempertimbangkan faktor lain yang dapat meningkatkan kualitas kinerja komite audit.

\section{Pengaruh Kepemilikan Institusional terhadap Financial Distress}

Signifikansi pada tabel 1 terkait dengan kepemilikan institusi menunjukkan bahwa H5 diterima. Hasil regresi logistik ini menunjukkan adanya pengaruh kepemilikan institusi terhadap financial distress bersifat signifikan dengan arah negatif, yang memiliki penjelasan apabila besarnya tingkat 
Refiana Dwi Maghfiroh \& Yuyun Isbanah. Pengaruh Audit Committee, Ownership Structure, dan Chief Executive Officer terhadap Financial Distress pada Perusahaan Sektor Perdagangan, Jasa, dan Investasi yang Terdaftar di Bursa Efek Indonesia pada Tahun 2015-2018

kepemilikan institusi, berdampak terhadap semakin rendah kemungkinan financial distress terjadi pada sebuah perusahaan. Donker et al., (2009) menyatakan adanya pemegang saham institusional memiliki tujuan untuk meningkatkan kinerja jangka panjang pada perusahaan, yang bertolak belakang dengan tujuan jangka pendek pihak manajemen perusahaan, sehingga peran dan tujuan pemegang saham institusi dapat berkontribusi pada peningkatan kinerja keuangan perusahaan dan menekan risiko perusahaan terdampak financial distress. Interpretasi teori hasil dari studi ini sependapat dengan teori agensi, di mana pemegang saham institusi dapat meminimalkan masalah keagenan karena pemegang saham institusi berperan sebagai agen pemantau pihak manajemen dan kebijakan perusahaan dalam melindungi hak para pemegang saham. Interpretasi praktis yang dapat dilakukan perusahaan dari hasil penelitian ini adalah perlunya meningkatkan persentase kepemilikan saham oleh pihak institusi karena dapat mengurangi risiko financial distress pada sebuah perusahaan. Upaya peningkatan ini dapat dilakukan dengan melakukan penawaran kerjasama dengan institusi lain serta menjaga hubungan baik perusahaan dengan pemegang saham institusi.

\section{Pengaruh Kepemilikan Manajerial terhadap Financial Distress}

Signifikansi kepemilikan manajerial pada tabel 1, mengindikasi bahwa H6 ditolak. Regresi logistik memaparkan bahwasannya tidak terdapat pengaruh bersifat signifikan terkait kepemilikan manajerial pada financial distress. Kepemilikkan manajerial pada studi ini dapat ditemukan baik di perusahaan financial distress maupun perusahaan non financial distress yang berdampak pada hasil studi berupa tidak adanya pengaruh secara signifikan kepemilikan manajerial pada financial distress. Kepemilikan manajerial tidak dapat dijadikan suatu prosedur yang tepat untuk menghilangkan konflik kepentingan antara pemilik saham dan manajer. Alasan lain juga dipicu karena baik atau tidaknya kinerja keuangan sebuah perusahaan tidak disebabkan oleh seberapa banyak saham oleh pihak manajemen namun bisa dipengaruhi oleh kemampuan pihak manajemen dalam mengelola perusahaannya. Interpretasi teori hasil studi ini berseberangan dengan adanya agency theory yang menekankan bahwa adanya kepemilikan manajerial bersifat menyetarakan kepentingan yang kontras antara pihak manajemen dengan pemilik saham, yang dapat menurunkan agency cost sehingga dapat mengurangi risiko financial distress. Interpretasi praktis dari temuan studi ini adalah perusahaan tidak perlu mempertimbangkan besar kecilnya persentase kepemilikan saham manjerial. Perusahaan dapat berupaya untuk melakukan peningkatan dan memperhatikan keahlian pihak manajemen dalam mengelola perusahaan.

\section{Pengaruh Kepemilikan Keluarga terhadap Financial Distress}

Nilai signifikansi kepemilikan keluarga pada tabel 1, mengartikan bahwasannya H7 tidak dapat diterima. Temuan pada analisa regresi logistik ini memperlihatkan bahwa kepemilikan keluarga tidak signifikan berpengaruh pada financial distress. Kepemilikan saham keluarga tidak memiliki dampak secara signifikan pada sebuah perusahaan agar terlepas dari financial distress. Hasil tersebut mengungkapkan bahwa jumlah persentase kepemilikan keluarga tidak dapat menghindarkan risiko financial distress ataupun memperbesar risiko perusahaan terkena financial distress. Adapun kepemilikan keluarga dijumpai pada sampel perusahaan yang tergolong financial distress dan perusahaan non financial distress. Kepemilikan keluarga secara tidak langsung pada sebuah perusahaan juga dapat menjadi suatu penyebab kurangnya kontrol keluarga secara langsung. Interpretasi teori temuan dalam studi ini menolak agency theory, yang menguraikan bahwa dengan adanya kepemilikan keluarga maka pihak keluarga memiliki insentif yang besar pada manajemen perusahaan dan memastikan jika perusahaan mempunyai kinerja yang baik dan dapat menjauhkan perusahaan dari risiko financial distress. Interpretasi praktis dari hasil studi adalah perusahaan tidak perlu mempertimbangkan peningkatan maupun penurunan kepemilikan saham oleh pihak keluarga karena berapapun persentase kepemilikan keluarga tidak ditemukan adanya pengaruh dengan financial distress. Upaya yang dapat diimplementasikan perusahaan adalah dengan meningkatkan kepemilikan institusi dikarenakan pihak institusi dapat memberikan pengaruh negatif terhadap ancaman financial distress. 


\section{Pengaruh Kepemilikan Pemerintah terhadap Financial Distress}

Berdasarkan uji yang dilakukan mengimplikasi bahwa H8 tidak diterima. Uji regresi logistik menjelaskan hasil bahwa tidak ada pengaruh yang bersifat signifikan atas kepemilikan pemerintah pada financial distress. Hasil tersebut dikarenakan kepemilikan pemerintah tidak dimiliki oleh semua sampel perusahaan dalam studi ini. Berdasarkan sampel dalam studi ini, diketahui bahwa terdapat dua perusahaan dari seluruh total sampel yang sahamnya dimiliki oleh pihak pemerintah. Minimnya persentase saham yang dikuasai pemerintah pada perusahaan disebabkan karena pemerintah lebih berfokus mengalirkan dananya pada perusahaan-perusahaan yang dimiliki negara. Kecilnya saham oleh pemerintah juga menjadi sebab lain mengapa kepemilikan pemerintah tidak mempunyai pengaruh dengan financial distress. Persentase kepemilikan yang sangat kecil berdampak pada kurangnya peran pemerintah dalam mengawasi dan menyelamatkan perusahaan dari risiko financial distress. Interpretasi teori pada penelitian ini tidak mendukung agency theory, di mana perusahaan dengan adanya kepemilikan pemerintah maka perusahaan akan memiliki perlindungan yang lebih kuat dari ancaman financial distress karena pihak pemerintah tidak akan mengabaikan kinerja dari perusahaan. Interpretasi praktis dari temuan ini adalah perusahaan perlu mempertimbangkan besarnya persentase kepemilikan saham pemerintah agar peran perlindungan pemerintah dalam sebuah perusahaan dapat lebih optimal sehingga kinerja perusahaan dapat ditingkatkan dan terhindari dari risiko financial distress.

\section{Pengaruh Kepemilikan Asing terhadap Financial Distress}

Berdasarkan temuan dari studi ini signifikansi kepemilikan asing pada tabel 1, menyatakan bahwa $\mathrm{H} 9$ tidak dapat diterima. Hasil regresi logistik menunjukkan apabila terdapat pengaruh yang tidak signifikan antara kepemilikan asing pada financial distress. Alasan yang menyebabkan kepemilikan asing tidak berpengaruh adalah dikarenakan kurangnya peran pemegang saham asing dalam hal pengawasan. Beberapa kendala diantaranya meliputi perbedaan negara pemegang saham dan lokasi perusahaan, serta pihak manajer profesional yang tidak memiliki saham dalam perusahaan tersebut berdampak pada minimnya pemantauan yang dilakukan oleh pemegang saham asing (Md-Rus et al., 2013), sehingga ada atau tidak kepemilikan asing di sebuah perusahaan tidak bisa menghasilkan dampak yang signifikan bagi perusahaan. Perbedaan persentase kepemilikan saham asing yang tidak terlalu berbeda antara perusahaan yang tergolong financial distress dengan perusahaan yang tergolong non financial distress juga menjadi salah satu alasan mengapa kepemilikan asing tidak menunjukkan adanya pengaruh pada financial distress. Intepretasi teori dalam studi menolak teori keagenan yang mendeskripsikan adanya pemegang saham asing pada perusahaan dapat berkontribusi sebagai pemantau dan pengendali yang baik, serta dapat memberikan insentif kepada pihak manajemen untuk memelihara kinerja dari perusahaan sehingga dapat memperkecil peluang financial distress. Intepretasi praktis terkait temuan penelitian ini adalah perusahaan tidak perlu memperhatikan tingkat persentase kepemilikan asing di perusahaan. Usaha yang dapat diimplementasikan adalah dengan menambah besar persentase kepemilikan diluar kepemilikan asing atau meningkatkan persentase kepemilikan institusi sehingga dapat meminimalkan ancaman financial distress.

\section{Pengaruh Kepemilikan Blockholder terhadap Financial Distress}

Hasil signifikansi kepemilikan blockholder pada tabel 1, mengindikasi bahwa H10 ditolak. Kepemilikan blockholder tidak ditemukan pengaruh yang bersifat signifikan pada financial distress yang ditunjukkan dalam regresi logistik. Minimnya jumlah perusahaan pada sektor dagang, jasa, serta investasi dalam sampel penelitian tidak memiliki kepemilikan blockholder. Terdapat 8 perusahaan dari seluruh total sampel yang memiliki kepemilikan blockholder dalam perusahaannya. Hal ini dikarenakan mayoritas kepemilikan saham pada sebuah perusahaan dimiliki oleh pihak institusi baik dalam negeri maupun asing. Kepemilikan blockholder juga dapat ditemukan di perusahaan financial distress maupun non financial distress serta Interpretasi teori hasil dalam studi ini tidak sesuai dengan agency theory, di mana kepemilikan blockholder dapat meminimalkan adanya masalah keagenan dalam sebuah perusahaan karena pemegang saham blockholder memiliki kontribusi untuk memantau tindakan dan keputusan yang diambil oleh manajer perusahaan, karena kepemilikan saham besar mereka dengan persentase kepemilikan lebih dari 5\%. Interpretasi praktis pada studi ini adalah perusahaan perlu mempertimbangkan adanya penambahan kepemilikan blockholder pada 
Refiana Dwi Maghfiroh \& Yuyun Isbanah. Pengaruh Audit Committee, Ownership Structure, dan Chief Executive Officer terhadap Financial Distress pada Perusahaan Sektor Perdagangan, Jasa, dan Investasi yang Terdaftar di Bursa Efek Indonesia pada Tahun 2015-2018

perusahaannya, karena adanya kepemilikan blockhoder dapat membantu proses pemantauan serta adanya insentif pada pihak manajerial agar bertindak selaras dengan kesejahteraan pemegang saham yang disebabkan oleh adanya pengendalian dari kepemilikan saham yang besar oleh blockholder.

\section{Pengaruh gender Chief Executive Officer (CEO) terhadap Financial Distress}

Output pada tabel 1 terkait gender CEO bisa diartikan bahwa H11 ditolak, dan mengindikasi bahwa tidak adanya pengaruh yang bersifat signifikan antara gender CEO dan financial distress. Hasil dalam studi ini diperoleh karena perusahaan sampel dalam studi ini, didominasi oleh direktur laki-laki, yaitu sebesar $89 \%$ dari seluruh sampel yang digunakan. Hasil tersebut membuktikan masih minimnya peran dan partisipasi wanita dalam memimpin sebuah perusahaan. Tingkat partisipasi yang rendah dapat disebabkan karena kurangnya kepercayaan masyarakat ketika perusahaan dipimpin oleh seorang wanita. Faktor lain juga disebabkan karena direktur wanita tidak dapat menghindarkan adanya financial distress pada perusahaan yang dipimpinnya. Seperti halnya pada PT. Sejahteraraya Anugrahjaya Tbk, selama periode 2015-2018 jabatan direktur diduduki oleh direktur bergender wanita, namun hal tersebut tidak memberikan dampak secara signifikan pada kondisi financial distress perusahan, sehingga.pada tahun 2015 dan 2018 perusahaan tidak dapat terlepas dari risiko financial distress. Interpretasi teori temuan penelitian ini tidak sejalan dengan agency theory, di mana perbedaan gender dalam memimpin sebuah perusahaan dapat memberikan pengaruh dan menentukan keberhasilan sebuah perusahaan sehingga dapat menghindarkan dari adanya ancaman financial distress. Interpretasi praktis dalam temuan studi ini adalah perusahaan tidak perlu mempertimbangkan gender CEO namun perusahaan lebih berfokus pada kompetensi yang dimiliki oleh CEO berperan sangat penting pada suatu perusahaan.

\section{KESIMPULAN}

Simpulan yang dapat diambil berdasarkan analisis temuan yang telah dilakukan adalah terdapat pengaruh positif frekuensi pertemuan komite audit dengan financial distress. Tingginya frekuensi pertemuan audit mengindikasi bahwasanya pertemuan komite audit bertujuan untuk menyelesaikan permasalahan yang terjadi pada perusahaan, sehingga hal tersebut berdampak pada tingginya risiko financial distress dalam suatu perusahaan. Hasil studi juga membuktikan bahwa kepemilikan institusional secara signifikan berpengaruh dan memiliki arah yang negatif pada kondisi financial distress. Tingginya persentase pemegang saham institusi dalam sebuah perusahaan akan memperketat pengawasan terhadap tindakan para manajemen sehingga berdampak pada minimnya masalah keagenan dan akan menekan keadaan financial distress. Hasil studi pada variabel lain yang meliputi ukuran komite audit, independensi komite audit, kompetensi komite audit, kepemilikan asing, kepemilikan blockholder, kepemilikan pemerintah, kepemilikan manajerial, kepemilikan keluarga, dan gender CEO menyatakan hasil yang tidak berpengaruh pada probabilitas financial distress.

Implikasi yang terkandung pada temuan studi adalah dengan memerhatikan frekuensi pertemuan komite audit dan persentase kepemilikan institusional pada sebuah perusahaan khususnya sektor pedagangan, jasa, dan investasi, di mana bagi perusahaan hal tersebut dapat dijadikan sebagai penentu strategi penunjang keberhasilan serta tindakan preventif dalam mencegah terjadinya financial distress dan bagi investor dapat dijadikan sebagai bahan pertimbangan sebelum memutuskan untuk berinvestasi pada perusahaan. Keterbatasan studi ini adalah rendahnya persentase kemampuan variabel independen dalam menjelaskan keberagaman variabel dependen, yang sebagian besar dijelaskan oleh variabel independen diluar penelitian ini. Sehingga disarankan agar studi selanjutnya dapat memperdalam pengaruh financial distress menggunakan variabel lain seperti leverage, operating capacity, ukuran perusahaan, kewarganegaraan komite audit, dan CEO quality, serta karakteristik lain dari variabel ownership structure yaitu kepemilikan saham pengendali dengan jumlah sampel dan objek penelitian yang berbeda serta periode penelitian yang lebih diperpanjang.

\section{DAFTAR PUSTAKA}

Abdullah, N., Ma'aji, M., \& Khaw, K. (2016). The value of governance variables in predicting 
financial distress among small and medium-sized enterprises in Malaysia. Asian Academy of Management Journal of Accounting and Finance, 12(December), 77-91.

Agustina, N., Rifa, D., \& Meihendri, M. (2015). Pengaruh Agency Cost,Corporate Governance dan Profitabilitas Terhadap Financial Distress. Jurnal Akuntansi, 7(1), 1-12. Retrieved from http://ejurnal.bunghatta.ac.id/index.php?journal=JFEK\&page=article\&op=view\&path $\% 5 \mathrm{~B} \% 5$ $\mathrm{D}=5587$

Altman, E. I., \& Hotchkiss, E. (2006). Corporate Financial Distress and Bankruptcy. In John Wiley \% Sons, Inc. https://doi.org/10.1002/9781118267806

Audit Quality Forum. (2005). AuditQuality Agency theory and the role of audit AuditQuality. Audit and Insurance Faculty.

Burke, R. (1994). Women on corporate boardsof directors: Forces for change? Women in Management Review, 9(1), 27-31. https://doi.org/10.1108/09649429410051006

Choy, S., Munusamy, J., Chelliah, S., \& Mandari, A. (2011). Effects of Financial Distress Condition on the Company Performance: A Malaysian Perspective. Review of Economics \& Finance, I(July 1997), 85-99. Retrieved from http://www.bapress.ca/Journal-4/Effects of Financial Distress Condition on the Company Performance-A Malaysian Perspective.pdf

Dalton, D., Daily, C., Johnson, J., \& Ellstrand, A. (1999). Number of directors and financial performance: A meta-analysis. Academy of Management Journal. https://doi.org/10.2307/256988

Donker, H., Santen, B., \& Zahir, S. (2009). Ownership structure and the likelihood of financial distress in the Netherlands. Applied Financial Economics, 19(21), 1687-1696. https://doi.org/10.1080/09603100802599647

Elloumi, F., \& Gueyié, J. P. (2001). Financial Distress and Corporate Governance: An Empirical Analysis. Corporate Governance: The International Journal of Business in Society, 1(1), 1523. https://doi.org/10.1108/14720700110389548

Fathonah, A. (2017). Pengaruh Penerapan Good Corporate Governance Terhadap Financial Distress. Jurnal Ilmiah Akuntansi, 1(2), 133-150. https://doi.org/10.23887/jia.v1i2.9989

FCGI. (2001). Seri Tata Kelola Perusahaan (Corporate Governance) The Roles of the Board of Commissioners and the Audit Committee in Corporate Governance. 37. Retrieved from http://www.fcgi.or.id

Fuad, N. (2017). The Impact of Audit Committee Characteristics on Financial Distress. Diponegoro Journal of Accounting, 6, 1-9.

Gunawijaya, I. (2015). Pengaruh Karakteristik Komite Audit, Independensi Dewan Komisaris, Reputasi Auditor terhadap Financial Distress. Jurnal Akuntansi Bisnis, 151(27), 10-17.

Hanifah, O., \& Purwanto, A. (2013). Pengaruh Struktur Corporate Governance dan Financial Indicators terhadap Kondisi Financial Distress. Diponegoro Journal of Accounting, 2, 1-15.

Hu, D., \& Zheng, H. (2015). Does ownership structure affect the degree of corporate financial distress in China? Journal of Accounting in Emerging Economies, 5(1), 35-50.

Jensen, M., \& Meckling, W. (1976). Value Engineering and the Lean Start-Up. Journal of Financial Economics, 3, 305-360. 
Refiana Dwi Maghfiroh \& Yuyun Isbanah. Pengaruh Audit Committee, Ownership Structure, dan Chief Executive Officer terhadap Financial Distress pada Perusahaan Sektor Perdagangan, Jasa, dan Investasi yang Terdaftar di Bursa Efek Indonesia pada Tahun 2015-2018

Kristanti, F., Rahayu, S., \& Huda, A. (2016). The Determinant of Financial Distress on Indonesia Family Firm. Procedia-Social and Behavioral Science, 219, 440-447.

Kristanti, M., \& Syafruddin, M. (2012). Pengaruh Karakteristik Komite Audit Pada Kondisi Financial Distress Perusahaan. Jurusan Akuntansi Fakultas Ekonomika Dan Bisnis Universitas Diponegoro, 1(1), 275-288.

Li, H. X., Wang, Z. J., \& Deng, X. L. (2008). Ownership, independent directors, agency costs and financial distress: Evidence from Chinese listed companies. Corporate Governance, 8(5), 622 636. https://doi.org/10.1108/14720700810913287

Manzaneque, M., Merino, E., \& Priego, A. M. (2016). The role of institutional shareholders as owners and directors and the financial distress likelihood. Evidence from a concentrated ownership context. European Management Journal, 34(4), 439-451. https://doi.org/10.1016/j.emj.2016.01.007

Manzaneque, M., Priego, A. M., \& Merino, E. (2016). Corporate governance effect on financial distress likelihood: Evidence from Spain. Revista de Contabilidad, 19(1), 111-121. https://doi.org/10.1016/j.rcsar.2015.04.001

Masak, F., \& Noviyanti, S. (2019). Pengaruh Karakteristik Komite Audit terhadap Financial Distress. International Journal of Social Science and Business, 3(3), 237.

McMullen, D., \& Raghunandan. (1996). Enhancing Audit Committee Effectiveness. Journal of Accountancy, 79.

Md-Rus, R., Mohd, K. N. T., Latif, R. A., \& Alassan, Z. N. (2013). Ownership Structure and Financial Distress. Journal of Advanced Management Science, (January), 363-367. https://doi.org/10.12720/joams.1.4.363-367

Miglani, S., Ahmed, K., \& Henry, D. (2015). Voluntary corporate governance structure and financial distress: Evidence from Australia. Journal of Contemporary Accounting and Economics, 11(1), 18-30. https://doi.org/10.1016/j.jcae.2014.12.005

Musallam, S., Fauzi, H., \& Nagu, N. (2019). Family, institutional investors ownerships and corporate performance: the case of Indonesia. Social Responsibility Journal, 15(1), 1-10.

Nuresa, A., \& Hadiprajitno, B. (2015). Financial Distress. Wiley Encyclopedia of Management, 2, 13. https://doi.org/10.1002/9781118785317.weom040039

Nurwaspodo, A. (2016). Pengaruh struktur kepemilikan perusahaan terhadap financial distress dengan leverage sebagai variabel kontrol. Diponegoro Journal of Accounting.

Panda, B., \& Leepsa, N. M. (2017). Agency theory: Review of theory and evidence on problems and perspectives. Indian Journal of Corporate Governance, 10(1), 74-95. https://doi.org/10.1177/0974686217701467

Platt, H. D., \& Platt, M. B. (2002). Predicting corporate financial distress: Reflections on choicebased sample bias. Journal of Economics and Finance, 26(2), 184-199.

Rahmat, M., Iskandar, T., \& Saleh, N. (2009). Audit committee characteristics in financially distressed and non-distressed companies. Managerial Auditing Journal, 24(7), 624-638. https://doi.org/10.1108/02686900910975350 
Rahmawati, E., \& Herlambang, P. (2018). Pengaruh Efektifitas Komite Audit Terhadap Financial Distress. Jurnal Reviu Akuntansi Dan Keuangan, 8(1), 53. https://doi.org/10.22219/jrak.v8i1.26

Revitasari, F., Nurdin, \& Azib. (2017). Pengaruh Karakteristik Komite Audit terhadap Financial Distress. Jurnal Manajemen Universitas Islam Bandung, 3, 289-293.

Rinaldi, A., Haryetti, \& Fathoni, A. F. (2014). Effect of Ownership Structure Financial Distress in Mining Company Listed on the Effect of Ownership Structure Financial Distress in Mining Company Listed on the Effect of Ownership Structure Financial Distress in the Mining Company Registered in Idx. Jurnal Online Mahasiswa Fakultas Ekonomi Universitas Riau, 1(2), 1-16.

Salloum, C., \& Azoury, N. (2012). Corporate governance and firms in financial distress: Evidence from a Middle Eastern country. International Journal of Business Governance and Ethics, 7(1), 1-17. https://doi.org/10.1504/IJBGE.2012.046102

Salloum, C., Azzi, G., \& Gebrayel, E. (2014). Audit Committee and Financial Distress in the Middle East Context: Evidence of the Lebanese Financial Institutions. International Strategic Management Review, 2(1), 39-45. https://doi.org/10.1016/j.ism.2014.09.001

Setiyani, D. (2014). Determinasi Karakteristik Komite Audit dalam Memprediksi Kondisi Financial Distress Stud Empiris Perusahaan Sektor Jasa yang Terdaftar di BEI tahun 2010-2012. Jurnal Akuntansi Indonesia, 3(1), 29-46.

Shahwan, M. (2015). The Effects of Corporate Governance on Financial Performance and Financial Distress. The International Jornal of Business in Society, 6(1), 334-348.

Sholikhah, P. (2018). Analisis Pengaruh CEO Gender, CEO Quality, Generation Family Firm terhadap Financial Distress pada Perusahaan Keluarga. International Journal of Machine Tools and Manufacture, 5(1), 86-96. https://doi.org/10.1016/j.ijmachtools.2009.09.004

Siagian, D. (2010). analisis pengaruh struktur corporate governance terhadap perusahaan yang mengalami financial distress. Media Riset Akuntansi, Auditing \& Informasi, 10, 46-64.

Sugiarto. (2009). Struktur Modal, Struktur Kepemilikan Perusahaan, Permasalahan Keagenan dan Informasi Asimetri. Yogyakarta: Graha Ilmu.

Sunarwijaya, I. (2017). Pengaruh Likuiditas, Leverage, Kepemilikan Manajerial, Dan Kepemilikan Institusional Terhadap Kemungkinan Terjadinya Financial Distress. Jurnal Ilmu Manajemen Mahasaraswati, 7(7).

Sundari, S., \& Amiruddin. (2015). Hubungan Antara Komite Audit Dengan Financial Distress. Jurnal Akuntansi Universitas Hasanuddin, 51-65.

Udin, S., Khan, M. A., \& Javid, A. Y. (2016). The Effects of Ownership Structure on likelihood of Financial Distress: An Empirical Evidence Article information: About Emerald www.emeraldinsight.com. International Journal of Business Society, 1-36. https://doi.org/https://doi.org/10.1108/CG-03-2016-0067 